\title{
PENGARUH MOTIVASI BELAJAR SISWA KELAS V TERHADAP PRESTASI BELAJAR MATEMATIKA DI SD NEGERI BEJIREJO KECAMATAN KUNDURAN KABUPATEN BLORA
}

\author{
Ari Indriani \\ Program Studi Pendidikan Matematika IKIP PGRI Bojonegoro \\ e-mail: ariindrianiemail@gmaiil.com
}

\begin{abstract}
The elementary school is the starting point of formal education in Indonesia. In this study used is a public primary schools Bejirejo Kunduran Blora District of the academic year 2013/2014. The sample used is the Elementary School fifth grade students Bejirejo, techniques used in data collection motivation questionnaire. As a precondition test using linearity and significance. While the hypothesis test using t-test. The conclusions of this research is the influence of fifth grade students' motivation to learn mathematics achievement in elementary school Bejirejo.
\end{abstract}

Keywords : motivation, matehmatics achievement and elementary school

\begin{abstract}
Abstrak: Sekolah Dasar merupakan titik awal dari pendidikan formal di Indonesia. Penelitian ini dilaksanakan di SD Negeri Bejirejo Kecamatan Kunduran Kabupaten Blora tahun ajaran 2013/2014. Sampel dalam penelitian ini adalah siswa kelas V SD Negeri Bejirejo, teknik pengumpulan data dengan menggunakan angket motivasi. Uji pendahuluan menggunakan linearitas dan signifikansi. Sedangkan uji hipotesis menggunakan uji t. Adapun hasil dari penelitian ini adalah adanya pengaruh motivasi belajar siswa kelas $\mathrm{V}$ terhadap prestasi belajar matematika di SD Negeri Bejirejo Kecamatan Kunduran Kabupaten Blora tahun ajaran 2013/2014.
\end{abstract}

Kata Kunci : motivasi, prestasi belajar dan sekolah dasar

\section{PENDAHULUAN}

Sekolah Dasar merupakan titik awal dari pendidikan formal di Indonesia. Diharapkan dari Sekolah Dasar ini nantinya akan dihasilkan sumber daya manusia yang berkualitas sebagai generasi penerus bangsa untuk mewujudkan tujuan luhur bangsa yaitu meningkatkan kualitas kehidupan manusia Indonesia sehingga terwujud masyarakat yang adil dan makmur berdasarkan Pancasila dan UUD 1945.

Mengingat pentingnya keberadaan Sekolah Dasar, maka pemerintah melalui Direktorat Jenderal Pendidikan Dasar Menengah (Dirjen Dikdasmen) terusmenerus menekankan peningkatan kualitas pendidikan di Sekolah Dasar. Mengenai pelaksanaan pendidikan Sekolah Dasar, Dirjen Dikdasmen melalui surat edaran No. 2931/C/1/1993 menyerukan untuk meningkatkan kualitas pengajaran tiga kemampuan dasar yaitu membaca, menulis dan berhitung di mana semua itu telah termuat pada mata pelajaran Bahasa Indonesia dan Matematika.

Matematika merupakan ilmu dasar yang mempunyai peranan penting dalam perkembangan ilmu dan teknologi. Sedangkan pada mata pelajaran matematika yang diajarkan di Sekolah Dasar dianggap mata pelajaran yang sulit bahkan menjadi momok dalam setiap kegiatan belajar mengajar. Akhirnya apa yang diharapkan dari prestasi belajar matematika, ternyata masih jauh dari harapan. Hal ini dapat 
dilihat dari hasil mata pelajaran matematika yang rendah dibanding dengan hasil mata pelajaran yang lainnya.

Pada mata pelajaran matematika, sepatasnya kita perlu prihatin. Matematika yang posisinya sebagai "ratu" sekaligus "pelayan" dari ilmu pengetahuan dan teknologi justru menjadi mata pelajaran yang dianggap paling sulit bahkan menjadi momok dalam setiap kegiatan belajar mengajar. Akhirnya apa yang diharapkan dari prestasi belajar matematika, ternyata masih jauh dari harapan. Hal ini dapat dilihat dari nilai matematika siswa SD di Kecamatan Kunduran adalah 6,00, misalnya pada pokok bahasan operasi bilangan bulat juga masih rendah. Sebagai contohnya: 5 $(-4)=9$ akan tetapi siswa banyak yang menjawab $5-(-4)=1$, sedangkan untuk -3 $-(-6)=-3$, banyak siswa yang menjawab -3 $-(-6)=-9$.

Kenyataan di atas menunjukkan masih rendahnya prestasi belajar matematika siswa Sekolah Dasar. Diduga banyak faktor yang mempengaruhi prestasi belajar matematika, misalnya metode pembelajaran, motivasi belajar, aktivitas belajar, kemampuan awal siswa yang berbeda, tingkat kecerdasan dan lain sebagainya.

Salah satu faktor yang menyebabkan prestasi belajar siswa rendah adalah motivasi belajar siswa. Hal ini dimungkinkan karena keingintahuan mereka tentang mata pelajaran matematika masih rendah, faktor dari luar (teman, keluarga, dan lingkungan) yang tidak mendukung untuk mempelajari mata pelajaran matematika dan lain sebagainya.

Sedangkan prestasi belajar matematika dipengaruhi oleh beberapa faktor misalnya aktifitas belajar belajar siswa, model pembelajaran yang digunakan guru dalam mengajar, kemampuan siswa dalam menerima pembelajaran yang diberikan oleh guru, motivasi belajar siswa dan lain sebagainya. Dalam penelitian ini dibahas tentang prestasi belajar yang dipengaruhi oleh motivasi belajar sisiwa, karena jika tidak ada motivasi dari siswa untuk belajar, maka selamanya siswa tidak akan tertarik dengan pelajaran matematika dan tidak memperoleh kepuasan dari belajar matematika dan belajar menjadi tidak bermakna.

Menurut Tu'u dalam Otong Kardisaputra (2004: 75) "prestasi merupakan hasil yang dicapai seseorang ketika mengerjakan tugas atau kegiatan". Sedangkan menurut Slameto (2003:2) "belajar adalah suatu proses usaha yang dilakukan seseorang untuk memperoleh suatu perubahan tingkah laku yang baru secara keseluruhan, sebagai hasil pengalamannya sendiri dalam interaksi dengan lingkungannya". Dan menurut James dan James dalam Maswins (2010), "matematika adalah ilmu tentang logika mengenai bentuk, susunan, besaran, dan konsep-konsep yang berhubungan satu dengan yang lainnya dengan jumlah yang banyak dan terbagi ke dalam tiga bidang yaitu aljabar, analisis, dan geometri". Dari pengertian di atas dapat disimpulkan, prestasi belajar matematika adalah hasil yang dicapai siswa dalam mengikuti pelajaran matematika yang mengakibatkan perubahan pada diri seseorang siswa berupa penguasaan dan kecakapan baru yang ditunjukkan dengan hasil yang berupa nilai.

Sedangkan faktor-faktor yang mempengaruhi belajar siswa banyak jenisnya, tetapai dapat digolongkan menjadi dua golongan saja, yaitu:

1) Faktor yang berasal dari diri sendiri (internal), meliputi:

a) Faktor jasmaniah (fisiologi) baik yang bersifat bawaan maupun yang diperoleh. Yang termasuk faktor ini adalah panca indera yang tidak berfungsi sebagaimana mestinya, seperti sakit, cacat tubuh atau 
perkembangan yang tidak sempurna, berfungsinya kelenjar tubuh yang membawa kelainan tingkah laku.

b) Faktor psikologi, sekurang-kurangnya ada tujuh faktor yang tergolong kedalam faktor psikologis yang mempengaruhi belajar. Faktor-faktor itu antara lain: intelegensi, perhatian, minat, bakat, motif, kematangan, dan kelelahan.

2) Faktor yang berasal dari luar diri (eksternal), meliputi:

a) Faktor keluarga yang meliputi: cara orang tua mendidik, relasi antara anggota keluarga, suasana rumah tangga, dan keadaan ekonomi keluarga.

b) Faktor sekolah faktor yang berasal dari sekolah antara lain: model pembelajaran, kurikulum, relasi guru dengan siswa, relasi siswa dengan siswa, disiplin sekolah, pelajaran dan waktu sekolah, standar pelajaran, keadaan gedung, model belajar siswa, dan tugas rumah.

c) Faktor masyarakat antara lain: kegiatan siswa dalam masyarakat, mass media, teman bergaul, dan bentuk kehidupan masyarakat. (Slameto, 2003 : 54-72)

Motivasi berasal dari kata "motif" yang artinya daya upaya yang mendorong seseorang untuk melakukan sesuatu. Motif dapat dikatakan sebagai daya penggerak dari dalam dan didalam subyek untuk melakukan aktivitas-aktivitas tertentu demi mencapai suatu tujuan. Berawal dari kata "motif", maka motivasi dapat diartikan sebagai daya penggerak yang telah menjadi aktif. Motif menjadi aktif pada saat-saat tertentu bila kebutuhan untuk mencapai tujuan sangat dirasakan atau mendesak.

Menurut Gambrell (2001) motivation theory has been discussed as an important aspect of students' success in schools. Research has shown that motivation influences students' involve- ment and academic achievement. There also is a growing interest in understanding the relationships between motivation and teacher-students' relationship. This study seeks to investigate the nature and magnitude of relationship between students'-faculty interactions, students' critical thingking skills, students'-to-students' relations and students' motivation.

Teori motivasi membicarakan tentang aspek yang penting bagi kesuksesan siswa di sekolah. Dalam penelitian mengatakan motivasi mempengaruhi keterlibatan dan prestasi akademik siswa. Penelitian ini menumbuhkan minat untuk mengerti hubungan antara motivasi dan hubungan guru dan siswa. Belajar mencari penelitian yang alami dan besarnya hubungan antara siswa, kemampuan berinteraksi, keahlian berpikir kritis siswa pada hubungan siswa dan motivasi siswa.

Menurut Sartain dalam Ngalim Purwanto (1990: 61), "motivasi adalah suatu pernyataan yang kompleks di dalam suatu organism yang mengarahkan tingkah laku terhadap suatu tujuan (goal) atau perangsang (incentive)". Tujuan (goal) adalah yang menentukan atau membatasi tingkah laku organism itu. Jika yang kita tekankan ialah faktanya atau objeknya, yang menarik organism itu, maka kita pergunakan istilah "perangsang (incentive)".

Dari beberapa definisi motivasi tersebut, pada dasarnya mengandung arti atau maksud yang sama yaitu bahwa motivasi adalah dorongan yang menyebabkan terjadinya suatu perbuatan guna mencapai suatu tujuan. Yang dimaksud motivasi dalam hal ini adalah motivasi belajar, yaitu suatu dorongan atau kemauan seseorang untuk melakukan aktivitas belajar agar prestasi belajar dapat dicapai.

Menurut Nanang Hanafiah dan $\mathrm{Cu}-$ 
cu Suhana (2009: 28-29) tinggi rendahnya motivasi belajar siswa dapat terlihat dari indikator motivasi itu sendiri. Mengukur motivasi belajar dapat diamati dari sisi-sisi, antara lain: durasi belajar, sikap terhadap belajar, frekuensi belajar, konsistensi terhadap belajar, kegigihan dalam belajar, loyalitas terhadap belajar, visi dalam belajar, achievement dalam belajar.

Menurut sifatnya motivasi dibagi menjadi dua yaitu motivasi intrinsik dan motivasi ekstrinsik. Motivasi intrinsik adalah motivasi/ dorongan yang dikarenakan orang tersebut senang melakukannya. Sebagai contoh orang yang senang membaca, ia sudah rajin mencari buku-buku untuk dibacanya. Sedangkan motivasi ekstrinsik adalah dorongan terhadap perilaku seseorang yang ada di luar perbuatan yang dilakukannya. Sebagai contoh seseorang itu belajar, karena besok pagi akan diadakan ujian dengan harapan mendapat nilai baik, sehingga akan mendapatkan penghargaan.

Prestasi belajar matematika juga dipengaruhi oleh motivasi belajar siswa. Karena jika tidak ada motivasi dari siswa untuk belajar, maka selamanya siswa tidak akan tertarik dengan pelajaran matematika dan tidak memperoleh kepuasan dari belajar matematika dan belajar menjadi tidak bermakna. Dengan demikian motivasi belajar siswa berpengaruh terhadap peningkatan prestasi belajar matematika.

\section{METODE}

Penelitian ini termasuk penelitian kausal komparatif. Adapun tujuan penelitian kausal komparatif yaitu untuk menyelidiki kemungkinan pertautan sebab akibat dengan cara melakukan pengamatan terhadap akibat yang ada dan kemudian mencari kembali faktor yang mungkin menjadi penyebab melalui data tertentu. Penelitian ini dilaksanakan di SD Negeri
Bejirejo Kecamatan Kunduran Kabupaten Blora tahun ajaran 2013/2014. Populasi dalam penelitian ini adalah seluruh siswa SD Negeri Bejirejo tahun ajaran 2013/2014, sedangkan sampel dalam penelitian ini adalah siswa kelas V SD Negeri Bejirejo yang berjumlah 15 orang. Metode pengumpulan data yang digunakan metode angket yaitu cara pengumpulan data melalui pengajuan pertanyaan-pertanyaan tertulis kepada subjek penelitian, responden, atau sumber data dan jawabannya diberikan secara tertulis. Angket yang digunakan adalah pilihan ganda yaitu suatu bentuk angket dimana siswa memilih jawaban yang disediakan. Sebelum angket digunakan, peneliti melakukan validitas isi, konsistensi internal dan reliabilitas terhadap angket tersebut. Penelitian ini menggunakan metode bantu dokumentasi. Menurut Suharsimi Arikunto (2006:158) dokumentasi di sini yaitu mencari data mengenai hal-hal atau variabel yang berupa catatan, transkip, buku, surat kabar, majalah, prasasti, notulen rapat, agenda, dan sebagainya. Metode ini digunakan untuk memperoleh data tentang daftar nama dan nilai siswa. Untuk mengukur prestasi belajar siswa, peneliti menggunakan nilai ujian akhir semester genap tahun ajaran 2013/2014. Pengujian prasyaratnya menggunakan uji linearitas dan keberartian. Sedangkan uji hipotesisnya menggunakan uji-t.

\section{HASIL DAN PEMBAHASAN}

Berdasarkan uji validitas isi, konsistensi internal dan reliabilitas, angket yang dapat digunakan dalam penelitian ini berjumlah 25 soal. Untuk mengetahui hubungan antara motivasi belajar dan prestasi belajar itu linear atau tidak digunakan uji anava. Hasil uji anava dapat dilihat pada tabel berikut:

Tabel 1 
Rangkuman Analisis Variansi Uji Linearitas

\begin{tabular}{lccccc}
\hline Sumber & JK & dk & RK & F $_{\text {obs }}$ & $F_{\text {tabel }}$ \\
\hline Regresi & 649,78 & 1 & 649,8 & 0,34 & 3,71 \\
\hline $\begin{array}{l}\text { Tuna } \\
\text { Cocok }\end{array}$ & 43,40 & 3 & 14,47 & & \\
\hline $\begin{array}{l}\text { Galat } \\
\text { Murni }\end{array}$ & 429,75 & 10 & 42,98 & & \\
\hline Total & 1122,9 & 14 & - & & \\
\hline
\end{tabular}

Hasil dari tabel di atas diperoleh nilai $\mathrm{F}_{\mathrm{obs}}<\mathrm{F}_{\text {tabel }}$ dan berdasarkan kriteria keputusan $\mathrm{H}_{0}$ diterima, sehingga kesimpulan yang diperoleh adalah adanya hubungan antara motivasi belajar dan prestasi belajar adalah linear. Sedangkan untuk melihat hubungan linear antara motivasi belajar dan prestasi belajar itu berarti atau tidak, digunakan uji anava. Adapun hasil pengujian anava dapat dilihat pada tabel berikut:

Tabel 2

Rangkuman Analisis Variansi Uji Keberar-

\begin{tabular}{lccccc}
\multicolumn{7}{c}{ tian } \\
\hline Sumber & JK & dk & RK & $\mathrm{F}_{\text {obs }}$ & $\mathrm{F}_{\text {tabel }}$ \\
\hline $\begin{array}{l}\text { Regresi } \\
\text { linear }\end{array}$ & 649,78 & 1 & 649,8 & 17,8 & 4,67 \\
\hline Galat & 473,15 & 13 & 36,4 & & \\
\hline Total & 1122,9 & 14 & & & \\
\hline
\end{tabular}

Hasil dari tabel di atas diperoleh nilai $\mathrm{F}_{\mathrm{obs}}>\mathrm{F} \alpha$ dan berdasarkan kriteria keputusan $\mathrm{H}_{0}$ ditolak, sehingga kesimpulan yang diperoleh adalah regresi linear antara motivasi belajar dan prestasi belajar berarti. Untuk mengetahui pengaruh motivasi belajar terhadap prestasi belajar maka digunakan uji-t. Adapun hasil dari uji-t adalah sebagai berikut:

Tabel 3

Rangkuman Uji-t

\begin{tabular}{|l|l|l|l|}
\hline Hipotesis Nol & $\mathbf{t}_{\text {obs }}$ & $\mathrm{t}_{\text {tabel }}$ & Keputusan \\
\hline$\beta=0$ & 4,23 & 2,16 & $\mathrm{H}_{0}$ ditolak \\
\hline
\end{tabular}

Berdasarkan tabel di atas maka dapat disimpulkan bahwa ada pengaruh motivasi belajar siswa terhadap prestasi belajar siswa pada mata pelajaran matematika. Dari tabel di atas juga menggambarkan persamaan regresi, yaitu:

$$
P=36,59+0,73 X
$$

di mana:

$\mathrm{X}=$ motivasi belajar siswa

$\mathrm{Y}=$ prestasi belajar siswa pada mata pelajaran matematika

persamaan di atas menunjukkan bahwa untuk koefisien regresi $\mathrm{X}$ sebesar 0,73 , yang mempunyai arti bahwa setiap penambahan satu poin motivasi belajar maka prestasi belajar siswa kelas $\mathrm{V}$ pada mata pelajaran matematika akan bertambah 0,73.

Hipotesis dalam penelitian ini adalah ada pengaruh motivasi belajar siswa terhadap prestasi belajar siswa kelas $\mathrm{V}$ mata pelajaran matematika di SD Negeri Bejirejo tahun ajaran 2012/2013. Hasil dari tabel 1 bahwa $F_{\text {obs }}=0,34<\mathrm{F}_{\text {tabel }}=3,71$, yang artinya adanya hubungan yang linear antara motivasi belajar siswa dengan prestasi belajar siswa. Hal ini memberikan pengertian bahwa motivasi belajar siswa sangat mempengaruhi prestasi belajar siswa. Sedangkan hasil dari tabel 2 adalah $\mathrm{F}_{\mathrm{obs}}=$ $17,85>\mathrm{F}_{\text {tabel }}=4,67$, yang artinya regresi linear antara motivasi belajar siswa dan prestasi belajar siswa berarti.

Setelah uji prasyarat memenuhi maka dilanjutkan dengan uji hipotesis dengan menggunakan uji-t. Adapun hasil uji-t pada tabel 3, yaitu $t_{\text {obs }}=4,23>t_{\text {tabel }}=$ 2,16 , yang artinya ada pengaruh motivasi belajar siswa terhadap prestasi belajar siswa kelas $\mathrm{V}$ pada mata pelajaran matematika. Hal ini juga ditunjukkan pada persamaan regresi yaitu $P=36,59+0,73 X$, yang artinya setiap motivasi belajar naik satu 
poin maka prestasi belajar siswa juga akan naik.

Prestasi belajar siswa dapat dipengaruhi beberapa faktor, salah satunya yaitu motivasi belajar. Hal ini dikarenakan siswa yang mempunyai motivasi untuk mempelajari mata pelajaran matematika maka siswa tersebut akan dapat mengikuti mata pelajaran dengan baik serta mampu mengerjakan soal-soal tentang mata pelajaran matematika. Motivasi siswa ini juga dipengaruhi dari faktor luar, misalnya keluarga dan teman. Jika keluarga dan teman tidak mendukung siswa dalam mengikuti mata pelajaran matematika maka nilai siswa tersebut akan rendah. Akan tetapi sebaliknya, jika keluarga dan teman mendukung siswa tersebut untuk mengikuti pelajaran matematika maka nilainya akan bagus. Motivasi belajar siswa kelas V SD Negeri Bejirejo mem-pengaruhi prestasi belajar matematika, karena dengan ada keingin untuk mempelajari mata pelajaran matematika maka nilainya akan meningkat.

\section{SIMPULAN}

\section{DAFTAR PUSTAKA}

Budiyono. 2009. Statistik untuk Penelitian. Surakarta: Sebelas Maret University Press.

2003. Metodologi Penelitian Pendidikan. Surakarta: Sebelas Maret University Press.

Indriani, Ari. 2011. Eksperimentasi Pendekatan Pembelajaran Kontekstual dan Problem Solving Pada Pembelajaran Matematika Ditinjau dari Motivasi Belajar Siswa Kelas V SD Negeri Sekecamatan Kunduran Blora Tahun Ajaran 2010/2011. Tesis. Program Pascasarjana Universitas Sebelas Maret.

John Rugutt, Caroline C Chemosit. 2009, Mar.What Motivates Students to
Berdasarkan hasil penelitian dan pembahasan di atas maka dapat disimpulkan bahwa adanya pengaruh motivasi belajar siswa kelas $\mathrm{V}$ terhadap prestasi belajar matematika di SD Negeri Bejirejo Kecamatan Kunduran Kabupaten Blora tahun ajaran 2013/2014. Para siswa diharapkan dapat meningkatkan motivasi belajar karena motivasi belajar merupakan salah satu faktor yang berpengaruh terhadap prestasi belajar siswa kelas V SD Negeri Bejirejo terutama mata pelajaran matematika. Guru diharapkan dapat membantu siswa tidak hanya dalam belajar akan tetapi dalam meningkatkan motivasi belajar siswa serta melakukan pendekatan dengan orang tua agar dapat membantu meningkatkan motivasi belajar siswa tersebut. Memanfaatkan fasilitas yang ada di sekolah agar motivasi siswa juga meningkat, misalnya menggunakan alat peraga yang tersedia. Kepada peneliti selanjutnya, diharapkan agar menyertakan variabel lain yang mungkin dapat mempengaruhi prestasi belajar siswa matematika di SD Negeri Bejirejo.

Learn? Contribution of Student-toStudent Relations, Student-Faculty Interaction And Critical Thinking Skills. Educational Research Quarterly. Vol. 32, Edisi 3; pg. 16, 13 pgs.

Otong Kardisaputra. Penelitian tentang manfaat tujuan pembelajaran khusus dalam proses belajar mengajar. http://educare.efkinpula.net/index.ph p?option $=$ com

Maswins. 2010, 20 Juni. Pengertian matematika. http://Maswins.com//

Nanang Hanafiah dan Cucu Suhana. 2009. Konsep Strategi Pembelajaran. Bandung: Refika Aditama. 
140 Jumal Ilmiah Pendidikan Matematika, Vol. 4 No. 2, hlm 134-139

ajar Dan Faktor-Faktor engaruhi. Jakarta: Rine- 